\title{
Lipids and lipolytic enzymes of the microalga Isochrysis galbana
}

\author{
Florence Hubert, Laurent Poisson* , Céline Loiseau, Laurent Gauvry, Gaëlle Pencréac'h, \\ Josiane Hérault and Françoise Ergan \\ Laboratoire Mer, Molécules, Santé (EA 2160), Université du Maine, IUT de Laval, 52 rue des Drs Calmette et Guérin, BP 2045, 53020 \\ Laval cedex, France
}

Received 27 January 2017 - Accepted 21 April 2017

\begin{abstract}
Marine microalgae are now well-known for their ability to produce omega-3 long chain polyunsaturated fatty acids (PUFAs) such as docosahexaenoic acid (DHA) and eicosapentaenoic acid (EPA). Among these microalgae, Isochrysis galbana has received increasing interest especially because of its high DHA content and its common use in hatchery to feed fish larvae and clams. Moreover, lipolysis occurring from the biomass harvest stage suggests that I. galbana may contain lipolytic enzymes with potential interesting selectivities. For these reasons, the potential of this microalga for the production of valuable lipids and lipolytic enzymes was investigated. Lipid analysis revealed that DHA is mainly located at the sn-2 position of the phospholipids. Thus, I. galbana was considered as an interesting starting material for the lipase catalyzed production of 1-lyso-2-DHA-phospholipids which are considered as convenient vehicles for the conveyance of DHA to the brain. Lipids from I. galbana can also be used for the enzymecatalyzed production of structured phospholipids containing one DHA and one medium chain fatty acid in order to combine interesting therapeutic and biological benefits. Starting from total RNA extract from I. galbana, coding sequences of putative lipolytic enzymes were obtained by RACE and Nested PCR. The heterologous expression of a sequence designated $\mathrm{IgTeCe}$ was implemented. An expression plasmid was constructed by ligating the coding sequence to a plasmid vector and then cloned and expressed in E. coli. Results showed the effective functionality of plasmid construction for the production of a recombinant protein with the expected molecular mass. Moreover, local alignment using BLASTP and biochemical evidences support the hypothesis that the expressed protein is a thioesterase.
\end{abstract}

Keywords: microalgae / $\omega-3$ polyunsaturated fatty acids / phospholipids / lipolytic enzymes

Résumé - Lipides et enzymes lipolytiques de la microalgue Isochrysis galbana. Les microalgues marines sont maintenant bien connues pour leur aptitude à produire des acides gras à longue chaîne de la série $\omega$-3 comme l'acide docosahexahénoïque (DHA) ou eicosapentaénoïque (EPA). Parmi ces microalgues, Isochrysis galbana connaît, ces dernières années, un intérêt croissant du fait d'un contenu lipidique riche en DHA et de son importante utilisation en écloserie pour nourrir les larves de poissons et les bivalves. D'autre part, la lipolyse souvent observée dès l'étape de collecte de la biomasse ainsi que la forte teneur en DHA suggère qu'I. galbana pourrait contenir des enzymes lipolytiques intéressantes en termes de sélectivité. Pour ces différentes raisons, le potentiel de cette microalgue pour la production de lipides d'intérêt et d'enzymes lipolytiques a été étudié. L'analyse des lipides d'I. galbana a tout d'abord révélé que le DHA était majoritairement greffé sur la position sn-2 des phospholipides. Dans ce contexte, les phospholipides d'I. galbana constituent une matière première intéressante pour la production, par voie enzymatique, de 1-lyso-2-DHA phospholipides, des composés intéressants pour optimiser le transport du DHA au niveau du cerveau. À partir des lipides d'I. galbana, on peut également envisager la production, toujours par voie enzymatique, de phospholipides structurés contenant du DHA et un acide gras à chaîne moyenne ce qui permet de combiner des intérêts thérapeutiques et biologiques intéressants. À partir des ARN totaux d'I. galbana, des séquences codant des enzymes lipolytiques putatives ont été obtenues par RACE et Nested PCR. L'expression hétérologue d'une séquence nommée IgTeCe a été initiée. Une construction plasmidique contenant la séquence codante a été clonée et exprimée avec E. coli. Les résultats ont montré que la

\footnotetext{
* Correspondence: laurent.poisson@univ-lemans.fr
} 
construction plasmidique permettait bien d'obtenir une protéine recombinante avec la masse moléculaire attendue. D'autre part, l'outil d'alignement local de séquences, BLASTP, ainsi que des données biochimiques ont permis de confirmer l'hypothèse que la protéine obtenue était une thioestérase.

Mots clés : microalgues / acide gras polyinsaturés $\omega-3$ / phospholipides / enzymes lipolytiques

\section{Introduction}

Microalgae are unicellular photosynthetic and eukaryotic organisms with a wide range of morphologies, shapes, sizes and aspects. Actually, the total number of algae species has been recently estimated to 72,500 despite some uncertainties regarding what organisms should be included as algae or microalgae (Guiry, 2012). Primary producers of the aquatic ecosystems, microalgae belong, along with the cyanobacteria, to the so-called "phytoplancton" consumed by zooplankton, fish larvae and clams. According to favorable conditions, microalgae have periods of fast growth called "bloom" that can cause red tides. Besides, these tides can sometimes be associated with the production of phycotoxins and lead to harmfull algal blooms (HAB) and shellfish poisoning (Masó and Garcés, 2006).

Boosted by the attracting market of biofuels, microalgae have received increasing interest during the last decade and today they are considered as sustainable natural factories for the production of a wide range of molecules with potential applications in the field of feed, food, cosmetics, pharmaceutics and energy (Mimouni et al., 2012; Person, 2010).

As photosynthetic organisms, microalgae are a source of pigments such as $\beta$-carotene, that can be found for instance in the halophilic strain Dunaliella salina cultivated on a large scale along the California coast. Other species like Porphyridium cruentum are also known to be sources of interesting polysaccharides. Nevertheless, the most promising biochemical compounds that can be found in microalgae are certainly the lipids for their $\omega-3$ fatty acids (Mimouni et al., 2015; Poisson et al., 2002) and mainly for the production of biodiesel which has been an important topic for several years now (Cadoret and Bernard, 2008).

However, according to many literature data, to be interesting from an economical point of view, biodiesel needs to be coproduced with other high added value molecules leading to the concepts of "bio-refinery" and "cellular milking" (Vinayak et al., 2015).

In this frame, the present paper is aimed at presenting the interest of the microalga Isochrysis galbana for the production of lipids and lipolytic enzymes with potential applications.

\section{Isochrysis galbana: an overview}

Isochrysis galbana is one of the species of the Isochrysidales order, belonging to the haptophyta division (phylum) (Fig. 1). Unlike other microalgae classified within the Isochrysidales such as Emiliana huxleyi, I. galbana has no dimorphic lifecycle and does not form calcareous cocoliths. Moreover, contrary to Emiliana huxleyi, I. galbana exhibits organic scales (Bendif et al., 2013).

First identified by Bruce, Knight and Parke in 1939, Isochrysis galbana is a rather small round to ovoid cell $(2-5 \mu \mathrm{m}$; $40-50 \mathrm{\mu m}^{3}$ ) bearing two smooth apical flagella (Fig. 1). In reference to the division name, the cells were also bearing
(A)

Empire : Eukaryota

Kingdom : Chromista

Phylum : Haptophyta

Class : Coccolithophyceae

Subclass : Prymnesiophyceae

Order : Isochrysidales

Family : Isochrysidaceae

Fig. 1. (A) Elements of classification; (B) photograph of Isochrysis galbana (photonic microscopy $\times 400$ ).

a reduced haptonema said "vestigial" inserted between the two flagella (Robert et al., 2004).

Up to date, two strains of Isochrysis were mainly described and studied in literature: T-Iso and Parke.

Isochrysis affinis galbana, more simply designated as T-iso, was formerly said to be a Tahitian clone conspecific with I. galbana Parke which originate from temperate zones. In link with its origin, T-Iso is capable of adapting to a much broader range of temperature and light conditions when comparing with I. galbana Parke (Ewart and Pruder, 1981; Tzovenis et al., 2003).

Apart from its plastid coloration which is more yellow, T-Iso is similar to Parke from a morphological point of view and no difference can be noticed nor by photonic microscopy nor by scanning electronic microscopy (SEM) (Robert et al., 2004).

In 2013, using, as molecular phylogenetic markers, the genes coding RNA small ribosomal subunit (SSU rRNA), Bendif et al. (2013) concluded that the genetic distance between T-Iso and I. galbana is sufficient to raise T-Iso as a new genius. This new genius was called Tisochrysis lutea in reference to the former name of the strain and to the yellow color of the cells.

In the same area, Pseudoisochrysis paradoxa was also renamed Isochrysis galbana.

Before this recent revision, the strains of Isochrysis were not always fully characterized and some confusion may have occurred in literature as already pointed, more generally for whole microalgae, by Muller-Feuga (1997).

I. galbana and T. lutea can be obtained worldwide in several culture collections under different specific strain codes (Tab. 1). This can also be a source of error in literature.

To be suitable in mollusc hatchery, algal cells have to present four main features:

- a size below $30 \mu \mathrm{m}$ or even $10 \mu \mathrm{m}$ for the early larval stages;

- devoided of cell wall or organs making their ingestion difficult;

- an adequate nutritional value;

- easy to cultivate on a large scale (Robert and Trintignac, 1997).

Combining these four features, I. galbana and more particularly Tisochrysis lutea were intensively used for years in hatchery to feed fish larvae and clams. 
Table 1. List of principal strain codes of Isochrysis galbana and relatives.

\begin{tabular}{|c|c|c|c|c|c|c|c|}
\hline Name & \multicolumn{5}{|l|}{ Strain code } & Isolator & Remark \\
\hline Isochrysis $\mathrm{sp}$. & CCAP 927/12 & PLY240 & & & RCC3709 & Butcher & l \\
\hline Isochrysis galbana Parke & CCAP 949/1 & PLY507 & CCMP715 & LB 1988 & RCC1353 & Ott & $\begin{array}{l}\text { Formerly Pseudoisochrysis } \\
\text { paradoxa }\end{array}$ \\
\hline Tisochrysis lutea & CCAP 927/14 & PLY506 & CCMP1324 & LB 2307 & RCC 1349 & Haines & 1 \\
\hline
\end{tabular}

CCAP: Culture Collection of Algae and Protozoa (UK); PLY: Plymouth (UK); NCMA: National Center for Marine Algae and Microbiota (formerly CCMP) (USA); UTEX: University of Texas (USA); RCC: Roscoff Culture Collection (France).

In the frame of the study concerning lipolytic enzymes, I. galbana Parke (CCAP 927/1) was cultivated on a lab scale on Provasoli $1 / 3$ medium in $500 \mathrm{~mL}$ Erlenmeyer flasks as previously described (Poisson and Ergan, 2001).

For the studies concerning lipids, larger amounts of biomass from I. galbana Parke (CCAP 927/1) and Tisochrysis lutea (CCAP 927/14) were obtained from Greensea (Mèze, France). The microalgae were cultivated in $100 \mathrm{~L}$ photobioreactors on sea water adjusted at $28 \mathrm{~g} . \mathrm{L}^{-1}$ with respect to salinity. Photobioreactors were incubated at $20^{\circ} \mathrm{C}$ under continuous illumination of $100 \mu \mathrm{E} \cdot \mathrm{m}^{-2} \cdot \mathrm{s}^{-1}$. Agitation was provided by air bubbling and $\mathrm{CO}_{2}$ injection. Microalgae were harvested by centrifugation in the early stationary phase when the lipid content is at the highest. Then, the vessel containing the harvested biomass was bathed in boiling water. The purpose of this step is to inhibit endogenous enzymatic activity; this is crucial since it allows to prevent the extent of lipolysis occurring in biomass during wet storage very shortly after harvest (Balduyck et al., 2016).

\section{Lipids}

Total lipids were extracted from the biomass using an optimized method derived from Folch et al. (1957) complemented by ultrasonic treatment (unpublished results).

Total lipids were classically separated by G60 silica gel chromatography using successively dichloromethane, acetone and methanol as eluting solvents. Total lipids and fatty acid analyses were carried out respectively by thin layer chromatography (TLC) and gas chromatography (GC) as previously described (Devos et al., 2006).

TLC of total lipids carried out by a double development in one dimension (Fig. 2) revealed the presence of three types of lipids:

- neutral lipids with sterol, triacylglerol and a ghost spot of free fatty acids;

- glycolipids with in particular sulfoquinovosyldiacylglycerides (SQDG) an interesting compound which is reported to have anti-tumoral and antiviral activities (Hossain et al., 2005; Plouguerné et al., 2013);

- phospholipids mostly containing phosphatidylcholine.

Table 2 shows fatty acid profiles obtained by GC. In total lipids, eight main fatty acids can be found from myristic acid (C14:0) to docosahexaenoic acid (C22:6-DHA) which represents $13.5 \%$ of the total fatty acids in I. galbana Parke (CCAP 927/1). DHA is a $\omega-3$ polyunsaturated fatty acid

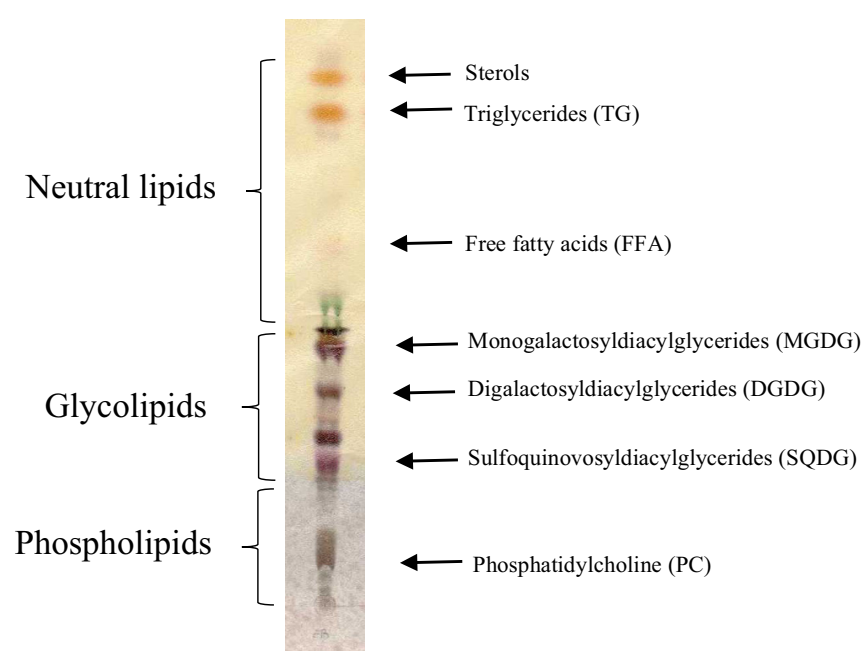

Fig. 2. Thin layer chromatography of Isochrysis galbana Parke (927/ 1) total lipids. Eluant 1 (half plate starting from the bottom): methyl acetate / propan-2-ol/ chloroform / methanol / $0.25 \%$ aqueous $\mathrm{KCl}$ (25/25/25/10/9); eluant 2 (entire plate): hexane/diethyl ether/glacial acetic acid (80/20/2); visualization: $\alpha$-naphtol solution; components were identified by comparison with standards analysed under the same conditions.

(PUFA) known for its health benefits on cardiovascular system and cognitive functions. However, its consumption is less than the recommended daily intake in most occidental countries (Barnathan, 2007; Bourre, 2005).

When comparing the fatty acid composition of the different lipid fractions, it can be assumed that the phospholipid composition is quite different from the two others with $25 \%$ of myristic acid and especially $50 \%$ of DHA which is pretty high. Similar results were obtained with T. lutea except for the content of linoleic acid which appeared to be higher when comparing with I. galbana Parke. Concerning T. lutea lipids, it can also be noticed that a mutant has been recently obtained by IFREMER Nantes leading to an increase of $80 \%$ for neutral lipids productivity (Bougaran et al., 2012).

To go further with I. galbana lipids, the location of DHA on the phospholipid backbone was determined. The phospholipids from I. galbana were submitted to hydrolysis catalyzed by a phospholipase A2 (PLA2). The time course of this reaction clearly showed that DHA was preferentially released so it can be concluded that DHA is mainly located at the sn-2 position (Devos et al., 2006). 
Table 2. Main fatty acids in lipids from Isochrysis galbana Parke (927/1) and Tisochrysis lutea.

\begin{tabular}{|c|c|c|c|c|c|c|c|c|c|}
\hline \multirow[t]{2}{*}{ Fatty acid } & \multirow[t]{2}{*}{ Common name } & \multicolumn{8}{|c|}{$\mathrm{wt} \%$ total fatty acids } \\
\hline & & $\mathrm{TL}$ & NL & GL & PL & $\mathrm{TL}$ & NL & GL & PL \\
\hline $\mathrm{C} 14: 0$ & Myristic acid & 18.0 & 11.8 & 21.4 & 25.3 & 14.6 & 9.6 & 13.3 & 20.4 \\
\hline $\mathrm{C} 16: 0$ & Palmitic acid & 8.8 & 13.8 & 10.5 & 10.1 & 12.3 & 16.0 & 14.6 & 5.3 \\
\hline C16:1 & Palmitoleic acid & 2 & l & / & l & / & 7.4 & 9.2 & / \\
\hline C18:3 & Linolenic acid & 11.4 & 11.0 & 15.4 & 0.8 & 8.9 & 4.8 & 12.9 & 0.8 \\
\hline $\mathrm{C} 18: 4$ & Stearidonic acid & 9.5 & 12.7 & 10.9 & 0.5 & 9.5 & 6.3 & 8.6 & 0 \\
\hline $\mathrm{C} 22: 6$ & Docosahexaenoic acid & 13.5 & 7.3 & 3.1 & 49.8 & 5.4 & 6.9 & 2.3 & 43.5 \\
\hline
\end{tabular}

TL:total lipids; NL: neutral lipids; GL: glycolipids; PL: phospholipids; /: not detected or not taken into account.

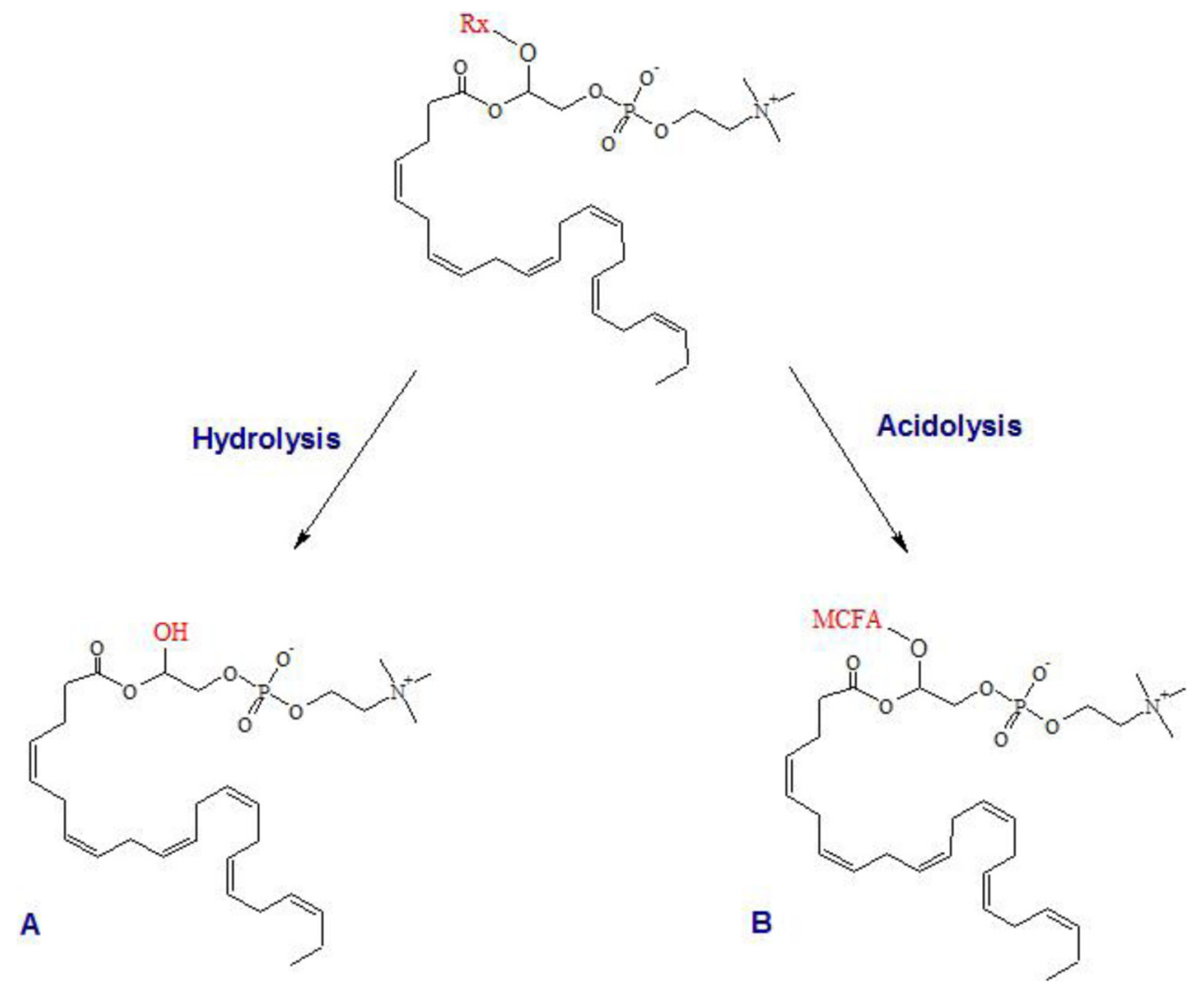

Fig. 3. Enzyme-catalyzed modification of phosphatidylcholine from Isochrysis galbana to obtain DHAlysophosphatidylcholine (A) and structured phosphatidylcholine containing DHA (B). Rx: nonspecific fatty acid; MCFA: specific mediumchain fatty acid.

Starting with this raw material, a selective deacylation can be implemented to produce lysophospholipids rich in DHA (Fig. 3A). In the last decade, several studies have contributed to suggest that lyso-PLs are convenient vehicles for an optimal absorption of DHA in the brain. Moreover, DHA is reported to be less suggested to oxidation when associated with phospholipids comparing with triglycerides (Pencréac'h et al., 2013).

Phospholipids from I. galbana appear also to be convenient for the production of structured phospholipids containing DHA and a medium chain fatty acid like caprylic acid (C8:0) with a view to combine rapid energy intake with health benefits (Fig. 3B). Moreover, it has been reported in literature that medium-chain fatty acids (MCFAs) may improve bioavailability of PUFAs (Lemarié et al., 2016). The production of
DHA lysophospholipids as well-tructured phospholipids can be achieved by enzymatic catalysis using more particularly lipases (Devos et al., 2006; Vikbjerg, 2006).

\section{Lipolytic enzymes}

As mentioned above, when biomass was not treated with boiling water, important amounts of free fatty acids are detected in the total lipid extracts: this may suggest the presence of endogenous lipolytic enzymes. Moreover, the high proportion of PUFAs in I. galbana could also suggest attractive enzyme specificities. Very few data can be found in literature concerning this point. For these reasons, the exploration of lipolytic enzymes from I. galbana Parke (CCAP 927/1) was implemented. 


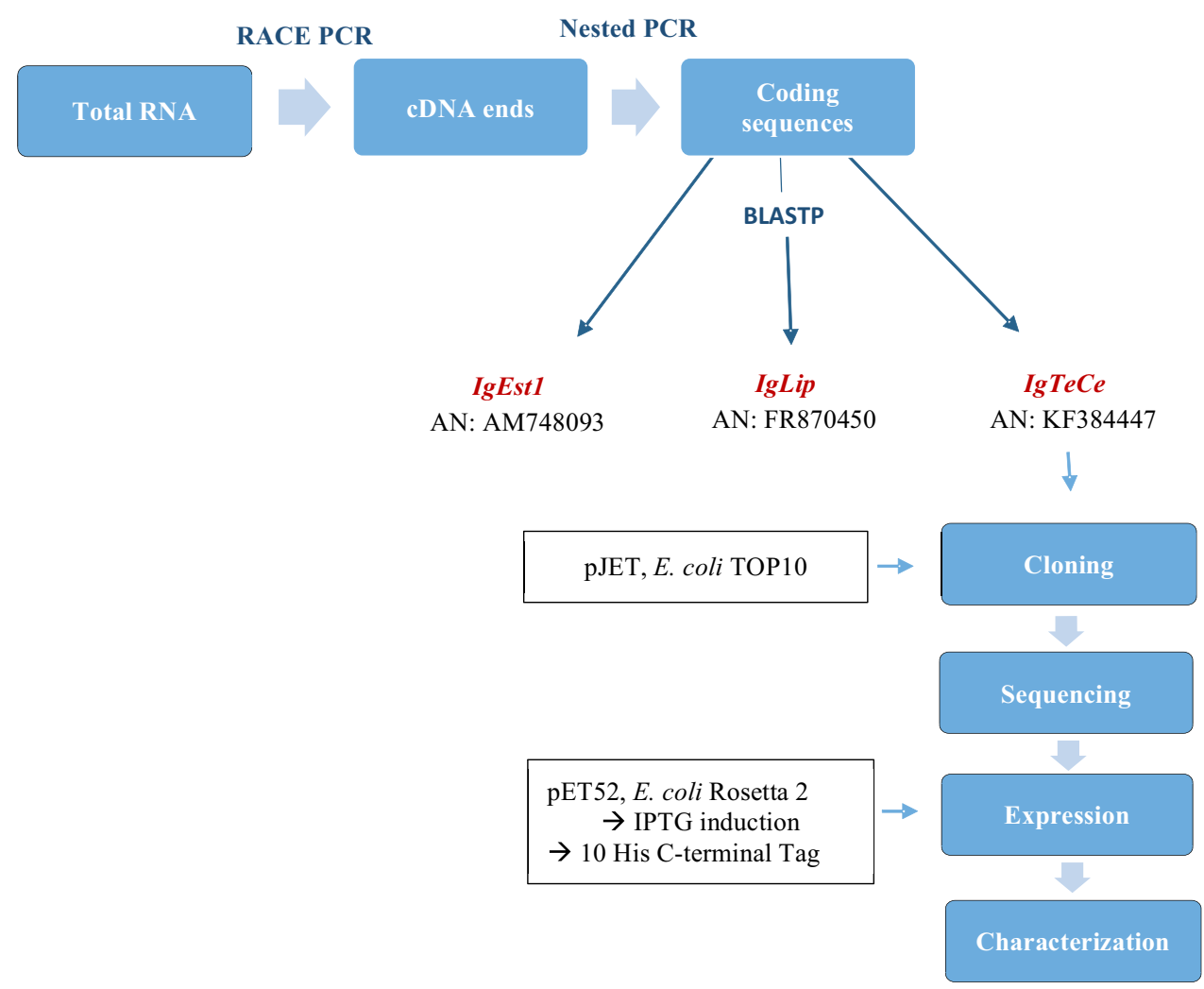

Fig. 4. General strategy for Isochrysis galbana lipolytic enzyme exploration and heterologous protein production.

Starting from the total mRNA extract, complete cDNA of putative lipolytic enzymes were obtained after RACE and Nested PCR (Fig. 4). Specific primers used for RACE and Nested PCR were designed by consulting I. galbana Express Sequence Tag Database. This protocol allowed to obtain three coding sequences. In silico analysis using BLASTP alignment led to assign the first sequence as being a putative esterase designated "Igest1" and registered under the accession number FR870450. The second sequence showed close relationships with fungal lipases and has been designated "Iglip" and recorded under the accession number FR870450. The third sequence was designated as "IgTeCe" standing for I. galbana thioesterasecarboxylesterase (Godet et al., 2010; 2012; Kerviel et al., 2014).

To go further, the heterologous expression of $\mathrm{IgTeCe}$ was then implemented. IgTeCe was ligated in pJET plasmid and cloned into E. coli strain TOP 10 (Fig. 4). Cloning products were verified by sequencing and the expression of $\mathrm{IgTeCe}$ was performed into $E$. coli strain Rosetta2 using the plasmid pET 52. It has to be noticed that pET 52 contains an induction system working with IPTG and allows for the production of a protein containing a deca-histidine C-terminal tag (Kerviel et al., 2014).

After expression, soluble proteins were submitted to SDSPAGE analysis (Fig. 5). No significant additional band can be clearly noticed on lane corresponding to the induced cells when comparing with the non-induced cells. Nevertheless, when the proteins were blotted and detected with Anti-His antibodies, the membrane revealed two bands only with the induced cells (Fig. 5). The major one agrees with the predicted size of the recombinant protein, that is to say $46.18 \mathrm{kDa}$. To explain the second band, the hypothesis of a phosphorylated form of the protein can be made. Reverse Transcriptase PCR

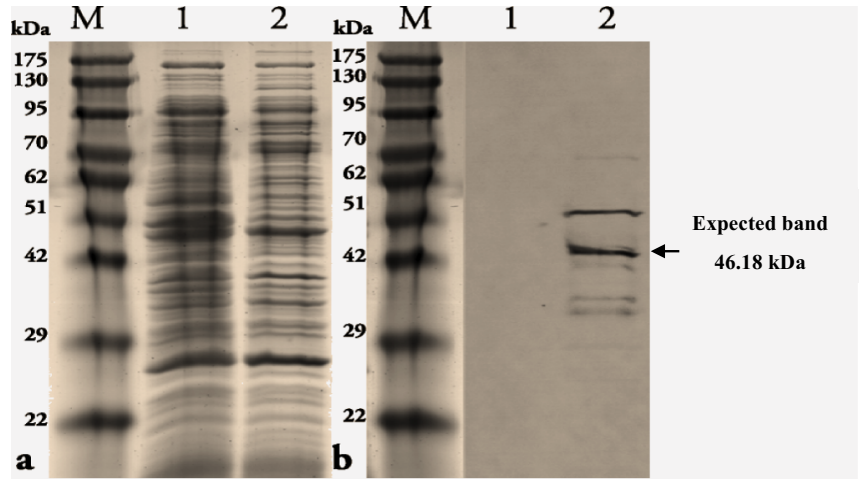

Fig. 5. SDS-PAGE (a) and western blot (b) analyses of soluble fraction of IgTeCe from E. coli. Lane M: Molecular mass (GeneDirex), lane 1: negative control, lane 2: induced cells with $1 \mathrm{mM}$ IPTG (from Kerviel et al., 2014).

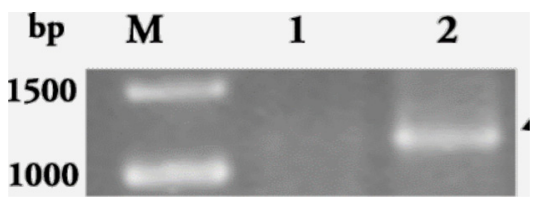

Fig. 6. RT-PCR analysis of the expression of IgTeCe gene after induction with $1 \mathrm{mM}$ IPTG. Lane M: molecular mass, lane 1: negative control, lane 2: cells induced with $1 \mathrm{mM}$ IPTG (from Kerviel et al., 2014).

implemented with primers specific of the IgTeCe gene, confirm that a transcript was only present when IPTG was added but not in the absence of IPTG (Fig. 6). 


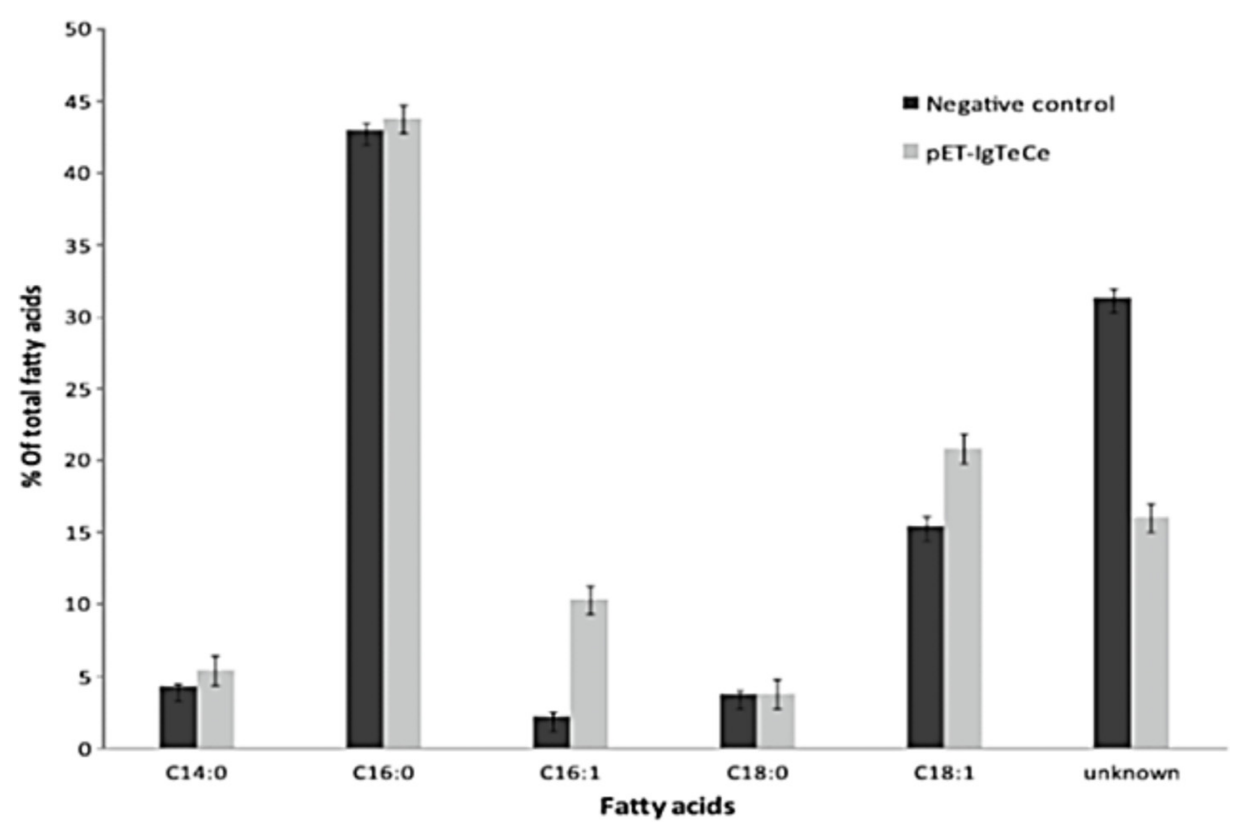

Fig. 7. Fatty acid composition of Escherichia coli strain expressing pET IgTeCe. Data are means of triplicates (from Kerviel et al., 2014).

By local alignment using BLASTP, the obtained protein displays similarities with thioesterases. To confirm this finding, the fatty acid profile of $E$. coli IPTG induced cells has been compared with $E$. coli non-induced cells. A fatty acid analysis of both cell types was carried out by GC (Fig. 7). A high proportion of palmitic acid and the presence of six other fatty acids can be noticed. Two other fatty acids remain unknown when comparing with all fatty acid standards available in the lab. Presumably, they could be branchedchain fatty acids commonly found in the lipids of bacteria. It appeared that $\operatorname{IgTeCe}$ expression led to an increase in palmitoleic acid (C16:1) from around $2 \%$ to $10 \%$ and an increase in oleic acid (C18:1) from 15\% to $21 \%$. On the other hand, the proportion of the two unknown fatty acids decreased. In literature, similar modification was observed with heterologous expression of acyl ACP thioesterase. Indeed, Chen et al. (2012) published very similar results with a thioesterase from peanut. Thus, the hypothesis that the expressed protein is a thioesterase appears to be consistent. Actually, thioesterase are quite interesting enzymes since they can be used to improve the release of free fatty acid and to alter the fatty acid profile with a view to obtain a particular lipid composition needed for a specific application such as biofuel production (Chen et al., 2012; Kerviel et al., 2014).

\section{Conclusion}

Apart from their potential in aquaculture I. galbana Parke and T. lutea also constitute an original source of phospholipids and enzymes with interesting applications in human nutrition and biotechnology. Nevertheless, to take the most of these molecules, they need to be integrated in a more complete valorization of high value compounds leading to a kind of "microalgae cracking". To make it feasible, an integrated approach needs to be implemented to explore I. galbana Parke and $T$. lutea from biomass production to product extraction and valorization. This may go through collaborative works specifically dedicated to these microalgae and through the building of comprehensive genomic and transcriptomic data catalogues.

Acknowledgements. This work was financially supported by "Laval agglomération" and the "conseil départemental de la Mayenne".

\section{References}

Balduyck L, Bijttebier S, Bruneel C, et al. 2016. Lipolysis in T-Isochrysis lutea during wet storage at different temperatures. Algal Res 18: 281-287.

Barnathan G. 2007. Sources connues et potentielles de DHA pour les besoins de 1'homme. OCL 14: 35-43.

Bendif EM, Probert I, Schroeder DC, de Vargas C. 2013. On the description of Tisochrysis lutea gen. nov. sp. nov. and Isochrysis nuda sp. nov. in the Isochrysidales, and the transfer of Dicrateria to the Prymnesiales (Haptophyta). J Appl Phycol 25: 1763-1776.

Bougaran G, Rouxel C, Dubois N, et al. 2012. Enhancement of neutral lipid productivity in the microalga Isochrysis affinis Galbana (T-Iso) by a mutation-selection procedure. Biotechnol Bioeng 109: 2737-2745.

Bourre JM. 2005. Dietary omega-3 fatty acids and psychiatry: mood, behaviour, stress, depression, dementia and aging. J Nutr Health Aging 9: 31-38.

Cadoret J-P, Bernard O. 2008. La production de biocarburant lipidique avec des microalgues : promesses et défis. J Soc Biol 202: 201-211.

Chen G, Peng Z, Shan L, et al. 2012. Cloning of Acyl-ACP thioesterase FatA from Arachis hypogaea L. and its expression in Escherichia coli. J Biomed Biotechnol 2012: 65257

Devos M, Poisson L, Ergan F, Pencreac'h G. 2006. Enzymatic hydrolysis of phospholipids from Isochrysis galbana for docosahexaenoic acid enrichment. Enzyme Microb Technol 39: 548-554. 
Ewart JW, Pruder GD. 1981. Comparative growth of Isochrysis galbana Parke and Isochrysis aff. Galbana, clone T-iso at four temperatures and three light intensities. J World Maric Soc 12: 333-339.

Godet S, Loiseau C, Pencréac'h G, Ergan F, Hérault J. 2010. Isolation and sequence analysis of a cDNA encoding a novel putative esterase from the marine microalga Isochrysis galbana (prymnesiophyceae, haptophyta). J Phycol 46: 679-684.

Godet S, Hérault J, Pencréac'h G, Ergan F, Loiseau C. 2012. Isolation and analysis of a gene from the marine microalga Isochrysis galbana that encodes a lipase-like protein. J Appl Phycol 24: 1547-1553.

Guiry MD. 2012. How many species of algae are there? J Phycol 48: 1057-1063.

Hossain Z, Kurihara H, Hosokawa M, Takahashi K. 2005. Growth inhibition and induction of differentiation and apoptosis mediated by sodium butyrate in caco-2 cells with algal glycolipids. Vitro Cell Dev Biol Anim 41: 154-159.

Kerviel V, Hérault J, Dumur J, Ergan F, Poisson L, Loiseau C. 2014. Cloning and expression of a gene from Isochrysis galbana modifying fatty acid profiles in Escherichia coli. J Appl Phycol 26: 2109-2115.

Lemarié F, Beauchamp E, Legrand P, Rioux V. 2016. Revisiting the metabolism and physiological functions of caprylic acid (C8:0) with special focus on ghrelin octanoylation. Biochimie 120: 40-48.

Masó M, Garcés E. 2006. Harmful microalgae blooms (HAB); problematic and conditions that induce them. Mar Pollut Bull 53: 620-630.

Mimouni V, Ulmann L, Pasquet V, et al. 2012. The potential of microalgae for the production of bioactive molecules of pharmaceutical interest. Curr Pharm Biotechnol 13: 2733-2750.
Mimouni V, Ulmann L, Haimeur A, Guéno F, Meskini N, Tremblin G. 2015. Marine microalgae used as food supplements and their implication in preventing cardiovascular diseases. OCL 22: D409.

Muller-Feuga A. 1997. Microalgues marines : les enjeux de la recherche. Document IFREMER. Available from http://archimer. ifremer.fr/.

Pencréac'h G, Ergan F, Poisson L. 2013. DHA-lysophospholipid Production. Curr Org Chem 17: 793-801.

Person, J. 2010. Algues, filières du futur. Livre turquoise. Adebiotech.

Plouguerné E, de Souza LM, Sassaki GL, et al. 2013. Antiviral sulfoquinovosyldiacylglycerols (SQDGs) from the Brazilian brown seaweed Sargassum vulgare. Mar Drugs 11: 4628-4640.

Poisson L, Ergan F. 2001. Docosahexaenoic acid ethyl esters from Isochrysis galbana. J Biotechnol 91: 75-81.

Poisson L, Devos M, Pencréac'h G, Ergan F. 2002. Acides gras polyinsaturés de microalgues : intérêts et développements actuels. OCL 9: 92-95.

Robert R, Trintignac P. 1997. Microalgues et nutrition larvaire en écloserie de mollusques. Haliotis 26: 1-13.

Robert R, Chretiennot-Dinet M-J, Kaas R, et al. 2004. Amélioration des productions phytoplanctoniques en écloserie de mollusques : caractérisation des microalgues fourrage. Document IFREMER. Available from http://archimer.ifremer.fr/.

Tzovenis I, De Pauw N, Sorgeloos P. 2003. Optimisation of T-ISO biomass production rich in essential fatty acids: I. Effect of different light regimes on growth and biomass production. Aquaculture 216: 203-222.

Vikbjerg AF. 2006. Enzyme catalyzed production of phospholipids with modified fatty acid profile. PhD thesis. BioCentrum Technical University of Denmark.

Vinayak V, Manoylov KM, Gateau H, et al. 2015. Diatom milking: a review and new approaches. Mar Drugs 13: 2629-2665.

Cite this article as: Hubert F, Poisson L, Loiseau C, Gauvry L, Pencréac'h G, Hérault J, Ergan F. 2017. Lipids and lipolytic enzymes of the microalga Isochrysis galbana. OCL 24(4): D407. 